\section{Top Management Team Shared Responsibility and Non-Financial Performance of Star-Rated Hotels in Uganda: The Moderating Role of Innovativeness}

International Journal of Economics, Business and Management Studies Vol. 8, No. 2, 24-37, 2021 e-ISSN: 2226-4809/p-ISSN: 2304-694.5

check for
updates

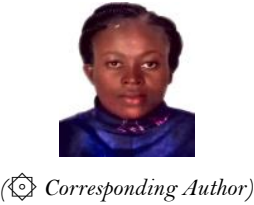

\author{
Arinaitwe Mercy ${ }^{1}$ \\ Rotich Dorothy ${ }^{2}$ \\ Muganda Catherine ${ }^{3}$
}

'Lecturer, Leisure and Hospitality Management, Makerere University Business School, Uganda. Email:marinaitwe@mubs.ac.ug

'Senior Lecturer. Hotel and Hospitality Management. Moi University, Kenya.

Email:djepkoech5@gmail.com

${ }^{s}$ Lecturer, Management Science and Entrepreneurship, MOI University, Kenya. Email:mugandacate@gmail.com

\title{
ABSTRACT
}

This study aimed to examine the moderating effect of innovativeness on the relationship between Top Management Team Shared Responsibility (TMT) and non-financial performance of star-rated hotels in Uganda. A positivism research philosophy and an explanatory research design with a crosssectional approach were adopted, while a multi-stage sampling technique; stratified and simple random techniques was used to collect quantitative data using self-administered questionnaires to a sample of 265 managers from 53 star-rated hotels. Both descriptive and inferential statistics were analyzed and a hierarchical regression model was used to test the set hypotheses. Results indicate a positive, significant relationship between TMT Shared Responsibility and non-financial performance. Innovativeness as a predictor of non-financial performance and also exerts a moderating effect on TMT Shared Responsibility and Non-financial performance of star-rated hotels in Uganda. Based on the findings the study concludes that under high level of innovation, TMT Shared Responsibility highly imprives non-financial performance of star rated hotels. Thus, hospitality management should create a conducive environment for innovativeness through research and development, rewarding creative ideas and responding to changes in the hospitality environment as these enhance performance. The novelty of this research resides in the moderating role of innovativeness in enhancing non-financial performance of star-rated hotels. Also, conceptualization of the TMT Shared Responsibility and innovativeness as intangible resources for enhanced performance.

Keywords: Top Management team shared responsibility, Non-financial performance, Innovativeness, Star-rated hotels, Uganda. JEL Classification: M19 Business Administration: Other.

DOI: $10.20448 / 802.82 .24 .37$

Citation | Arinaitwe Mercy; Rotich Dorothy; Muganda Catherine (2021). Top Management Team Shared Responsibility and NonFinancial Performance of Star-Rated Hotels in Uganda: The Moderating Role of Innovativeness. International Journal of Economics, Business and Management Studies, 8(2): 24-37.

Copyright: This work is licensed under a Creative Commons Attribution 3.0 License

Funding: This study received no specific financial support.

Competing Interests: The authors declare that they have no competing interests.

History: Received: 22 September 2021/ Revised: 27 October 2021/ Accepted: 19 November 2021/ Published: 8 December 2021

Publisher: Online Science Publishing 


\section{Highlights of this paper}

- The study investigated the moderating effect of innovativeness on the relationship between Top Management Team Shared Responsibility (TMT) and non-financial performance of star-rated hotels in Uganda.

- Innovativeness as a predictor of non-financial performance and also exerts a moderating effect on TMT Shared Responsibility and Non-financial performance of star-rated hotels in Uganda.

- Hospitality management should create a conducive environment for innovativeness through research and development, rewarding creative ideas and responding to changes in the hospitality environment as these enhance performance.

\section{INTRODUCTION}

Performance of firms has been recognized as core to businesses in achieving firm objective and realizing firm optimal output. However, there has been questions among researcher and scholars on why some fail while others succeed (Ongori, Iravo, \& Munene, 2013) and this has influenced studies on the drivers of firm performance. This study focuses on the hotel sector, which is one of the most crucial sectors both nationally and worldwide. For example, the Statistics (2017) report indicates that the Uganda hotel industry contributes highly to the GDP with $95 \%$ of the hotels being owned by indigenous people, while in 2018, the hotel sector generated 10.4\% of global GDP and approximately 320 million jobs worldwide (Sofronov, 2018).

Certainly, performance of firm entails actual output as measured against its projected objectives goals and outputs, thus academicians, as well as hotel management practitioners, have suggested various parameters to measure performance (Sainaghi, Phillips, \& Zavarrone, 2017). However, a debate of which parameter is more appropriate between the financials and non-financials continues to grow. In this regard, some authors have posit that there are various shortfalls with use of purely financial performance measures (Abernethy, Bouwens, \& Van Lent, 2013). Based on empirical evidence on current practice of non-financial performance measures, this study focuses on non-financial performance that has been advanced by some studies, as the major point of focus is to ensure a firm's long-term success (Sainaghi, 2011). Despite the perceived importance of the hotel industry, the current performance is still poor as evidenced by the high collapse rates due to very low occupancy that star-rated hotels continue to face. According to Omagon (2019), occupancy has declined since 2010 from a rate ranging between $70 \%$ to $90 \%$ dropping to a range of $28 \%$ and $50 \%$. It has been argued that this may be due to the lack of coordination in the managerial workforce (O'Reilly, Caldwell, Chatman, Lapiz, \& Self, 2010) limited innovativeness which is extremely important for the service business (Gomezelj \& Smolčić, 2016). Managers' incapacity to convert resources into value, imitable capabilities and performance can also be blamed for poor performance (Nath, Nachiappan, \& Ramanathan, 2010).

There are numerous ways to think about the resources needed to improve a company's success. The concept of shared accountability by the Top Management Team (TMT) is used in this stud as a way to capture how managers identify environmental opportunities and threats, interpret relevant information, consider organizational capabilities and constraints to formulate and implement strategic change (O'Reilly et al., 2010). TMT Shared Responsibility is conceptualized as the extent to which the upper echelon team of a firm take the decisions together and are responsible for them (Mihalache, Jansen, Van den Bosch, \& Volberda, 2014). Furthermore, scholars' research interest in top managers' roles in organizations continues to grow in order to determine how they influence organizational outcomes, with the general conclusion being that managers play a critical role in firm performance (Martin, 2011). It is especially important for the TMT of star-rated hotels to embrace shared responsibility because they are thought to invest heavily to achieve the star-rating. It is also believed that a hotel's performance is a function of the combined efforts of various departments, involving both the front office; reception, 
food and beverage service, and the back office; kitchen and rooms (Hsieh \& Lin, 2010). Much as research has established that the lack of TMT Shared Responsibility is a critical impediment to firm performance (Mihalache et al., 2014), studies explaining this relationship are few with calls for further research to improve our understanding of this relationship. This study therefore seeks to untangle the undefined relationship between TMT Shared Responsibility and Non-financial performance of star-rated hotels by revealing the moderating role of innovativeness.

The resource-based perspective shows how incomparable resources affect company performance. Various forms of resources have been highlighted as being significant for the realization of increased hotel sector performance (Hernández-Perlines, Ibarra Cisneros, Ribeiro-Soriano, \& Mogorrón-Guerrero, 2020) and other sectors (Dawa et al., 2021). We sought to add innovativeness to this abundance of knowledge by bridging the gap between TMT Shared Responsibility and performance outcomes. This study suggests that while TMT Shared Responsibility is an important capability, innovativeness provides a lot more clarity in explaining firm performance.

Conceptualization of firm performance and its antecedents through the angle of the hotel sector this research environment for this study was chosen because hotels are the most major and well-known type of overnight accommodation in the world, selling offerings that include a mix of intangible service and tangible commodities components (Tajeddini, 2010). Because of this significant contribution to the tourist industry, extensive study on the behavior of hospitality establishments and stakeholders has been conducted (Gomezelj \& Smolčić, 2016).

According to Omagon (2019), there are 62 star-rated hotels registered under the Uganda Hotel Owners' association since the hotel grading system was introduced in 2015 and recognized by the Uganda Tourism Board. The star-hotels range from five-star to two-star and are distributed across the country with $8 \%$ being 5 -star-hotels, $30 \%$ being 4 -star hotels, $27 \%$ being 3 -star hotels while $43 \%$ are 2 -star hotels. One of the challenges that star-rated hotels face is that while they invest heavily to attain the star-ratings, they still face stiff competition from other hospitality establishments, which are estimated to be about 3000 ranging from guesthouses, motels, inns, resorts and lodges according to the Uganda Hotel Owner's Association (Omagon, 2019). The ability to recognize the valuable resources and capabilities of TMT Shared Responsibility and innovativeness is therefore crucial.

\subsection{Theoretical Framework}

The resource-based view theory of a firm (Barney, 1991) has been widely employed to research organizational strategy. According Asad, Sharif, and Hafeez (2016) resource-based view theory considers companies to have a distinct collection of tangible and intangible assets and competencies that enable them to achieve a competitive edge and superior performance. The resource-based theory is appropriate for understanding the non-financial performance of star-rated hotels because it describes how firms gain competitive advantage from the resources and capabilities they currently possess or can acquire (Agyapong, Essuman, \& Afia Kesewa Yeboah, 2021). Star-rated hotels tend to be competitive to maintain or improve the star-rating and are usually dependent on the top managements' ability to obtain market information and make quick strategic decisions collectively.

The resource-based theory is applied to this study by suggesting that star-rated hotels have incomparable resources such as TMT Shared Responsibility and Innovation, which they must deploy to achieve firm performance. Competences, an inexhaustible resource, have been shown to influence business success in the past since they offer a firm with competitiveness (Mitchelmore \& Rowley, 2013). On this basis, it is reasonable to conclude that managers and their capacity to share responsibility are a significant and important resource for the company.

Hotel managers head different departments but their separate performance is interdependent and crucial for the overall performance. 
Firm performance results from a combination of firm-specific resources such as new knowledge, products and services (West \& Noel, 2009). Innovativeness is therefore a key resource described in the literature. Firms are able to create a broad set of skills (Gomezelj \& Smolčić, 2016) which are valuable tools for competitiveness (Teixeira \& Ferreira, 2019) and survival in the an ever revolving business environment (Sainaghi et al., 2017). Ultimately, innovativeness enables firms to align their other resources with overall firm performance.

\section{HYPOTHESES DEVELOPMENT}

\subsection{Top Management Team (TMT) Shared Responsibility and Firm Performance}

The relevance of the TMT in influencing firm performance has encouraged academic interest over time. According to Mitchelmore and Rowley (2013) firm growth and performance has be identified as antecedents of workforce's competencies, particularly the Top Management who are in control of the firm's strategic planning. The phrase trans-active memory is used in team literature to describe the combination of each individual's knowledge and a collective awareness (Hollingshead, Brandon, Yoon, \& Gupta, 2011).

According to Mihalache et al. (2014), there is limited understanding of the relationship between TMT Shared Responsibility and firm performance. The structural environment of an organization, as expressed in organizational units' decision autonomy and shared accountability, may affect the relationship between its alignment, adaptability, and performance objectives (Errays \& Hattabou, 2015). The study found that when individual organizational units share responsibility for the overall performance of the organization, the performance effects of adaptability are stronger, and the findings show that the relationship between adaptability and performance is positive at high levels of shared responsibility and neutral at low levels of shared responsibility.

Based on the above discussion, the following hypothesis emerges:

H1. There is a significant positive relationship between TMT Shared Responsibility and non-financial performance.

\subsection{Innovativeness and Non-Financial Performance}

The proclivity of firms to participate in and support new ideas that may result in new technological products, services, or processes has been defined as their innovativeness (Anjani \& Yasa, 2019). Innovative hotel products and services include a wide range of factors, such as establishing online check-in and checkout systems in which the customer becomes a co-creator in the innovation process (Sarmah, Kamboj, \& Rahman, 2017). Firms can thus develop a diverse set of skills and knowledge (Omerzel \& Antoncic, 2008), which are valuable tools for competitiveness and continued existence in a constantly changing business environment (Sainaghi et al., 2017; Teixeira \& Ferreira, 2019). Moreover, it is believed that the development of new technologies, products, and services through innovation (Anjani \& Yasa, 2019) enables business success (Carmona-Márquez, Leal-Millán, Vázquez-Sánchez, Leal-Rodríguez, \& Eldridge, 2016), which is credited to the firm's innovative capacity (Prifti \& Alimehmeti, 2017), since previous studies have shown that an increase in innovation results in an increase in positive business performance outcomes.

\subsection{Innovativeness as a Moderator}

A review of the literature that provides empirical conclusions about the moderating effects of product/service innovativeness reveals that there are few studies in the literature for operationalizing innovativeness as an intervening variable (Hatak, Kautonen, Fink, \& Kansikas, 2016) especially in hospitality performance research. Nevertheless, some performance studies exist that conceptualize innovativeness as a mediator (Al-Momani, Mahmoud, \& Ahmad, 2018) with limited studies focusing on the moderation effect. For example, Li, Liu, and Zhou 
(2018) evaluated innovativeness, as a moderator on the relationship between market orientation and performance in small Chinese firms. The previous results revealed innovativeness to act as a positive moderator.

In relation, this study further draws support from previous research where it has been asserted that innovativeness is a managerial role and moderates the relationship between firm performance and its predictors (Wang \& Dass, 2017). Firm managers therefore have the responsibility to introduce new services that improve quality, thereby both meeting the changing requirements of potential customers and positively changing the customer perception of the firm image (Glynn \& Chen, 2009). In this paper, it is argued that both innovativeness and TMT Shared Responsibility are necessary to enhance firm performance because if moderation effect is found to be correct, then by modifying either of the two, a star-rated hotel should have positive performance outcomes, which should be higher with increased innovativeness.

It is therefore hypothesized that:

H2. Innovativeness significantly and positively influences non-financial performance star-rated hotels

H3. Innovativeness moderates the relationship between TMT Shared Responsibility and non- financial performance starrated hotels

\section{METHODOLOGY}

\subsection{Design, Population and Sample}

This study was based on field research conducted from April 13th to April 15th, 2021, which used a crosssectional research design and involved the use of questionnaires to collect original quantitative data from star-rated hotel managers who head the departments of general manager's office, Food \& Beverage service, Kitchen, Rooms, and front office/reception because they have a clear understanding of the performance of their departments, which contribute to the overall hotel performance. Stratified and simple random sampling techniques were used to obtain a sample of 265 managers $\left(53^{*} 5\right)$ by selecting 5 managers from each of the sampled 53 star-rated hotels from a population of 62 star-rated hotels.

\subsection{Measurement of Study Variables}

All variables used in this study, were measured on a five- point Linkert scale using items adopted from previous studies and modified to fit the current study context. The dependent variable; (Non-Financial Performance) was measured using non-financial indicators based on parameters that were commonly used by hospitality scholars as applicable to hotels. Ten items were adopted to cover customer satisfaction (Chen, Hsu, \& Tzeng, 2011; Wadongo, Odhuno, Kambona, \& Othuon, 2010), Timely and Quality service and Hotel image (Avci, Madanoglu, \& Okumus, 2011).

TMT Shared Responsibility was measured by six items to capture the extent to which team members perceive they have responsibility and authority, how their departments behave towards each other and how the general manager involves the other team members in decisions about aspects of day-to-day operations (Ling, Simsek, Lubatkin, \& Veiga, 2008). Finally, eight items were used to measure the moderator; Innovativeness in terms of hotels' ability formulate new products, services and processes (Covin \& Miller, 2014; Grissemann, Plank, \& Brunner-Sperdin, 2013; Kantur, 2016).

\subsection{Control Variables}

The study has four covariates namely; age, gender, highest level of education and Tenure have all been previously found to significantly affect firm performance hence should be monitored by being included in the model. 
For example, studies have all indicated that the level of education and tenure have a significant effect on the ability of managers to make the right strategic decisions and consequently enhance firm performance (Kusumasari, 2018). Gender was measured as “o” for Female and “1" for Male while the respondents' age also believed to affect performance (Shrestha, 2019) was grouped into four categories 21 - 30 years, 31 - 40 years, 41 - 50 years, over 50 years) and the respondents' highest level of education was categorized as; Diploma, Degree, Post Graduate, and Others.

\section{FINDINGS}

\subsection{Sample Characteristics}

The 265 (two hundred and sixty-five) self-administered questionnaires, of which 260 were recovered but only 247 were used because 18 of them were not properly filled and thus excluded from the analysis. This equated to a 93.2 percent response rate. Table 1 gives a summary of the demographic characteristics of respondents, which reveals that the majority of respondents $(n=157)$ were between the ages of 31 and 40, with a $63.6 \%$, followed by those between the ages of 21 and 30 , with a $21.1 \%(n=52)$. The other age group were those of ages 41-50 representing $15.0 \%(n=37)$, then those aged over $50(n=1,4 \%)$ were the least. The males outnumbered the females by a margin of $62.8 \%(n=155)$, while female was represented by $37.2 \%$, $(n=92)$. Majority of the respondents, 98 $(39.7 \%)$ were degree holders while 60 (24.3\%) had attained post graduate qualifications, followed by Diploma holders who were 59(23.9\%) and the rest (others) who didn't fall in the specified education levels were 30 (12. $1 \%$ ). Majority of the respondents had worked in the hotel for 4-6 years, $(\mathrm{n}=138)$ with a $(55.9 \%)$, which was followed by those who had worked for less than 3 years with a $27.5 \%$, $(n=68)$. Those who had worked for 7-8years were 31 $(12.6 \%)$, while those who had worked for more than 8 years were represented by $n=10(4 \%)$ were the least.

Table-1. Demographic attributes.

\begin{tabular}{llcc}
\hline Demographic attributes & & Frequency & Percentage (\%) \\
\hline Manager's age group & $21-30$ & 52 & 21.1 \\
\cline { 2 - 4 } & $31-40$ & 157 & 63.6 \\
\cline { 2 - 4 } & $41-50$ & 37 & 15.0 \\
\cline { 2 - 4 } Gender & Over 50 & 1 & 4 \\
\cline { 2 - 4 } & Total & 247 & 100.0 \\
\hline \multirow{5}{*}{ Highest Education Level } & Male & 155 & 62.8 \\
\cline { 2 - 4 } & Female & 92 & 37.2 \\
\cline { 2 - 4 } & & 247 & 100.0 \\
& Diploma & 59 & 23.9 \\
\cline { 2 - 4 } & Degree & 98 & 39.7 \\
\cline { 2 - 4 } & Post Graduate & 60 & 24.3 \\
\cline { 2 - 4 } & Others & 30 & 12.1 \\
\cline { 2 - 4 } & Total & 247 & 27.5 \\
\hline \multirow{5}{*}{ Tenure } & Less than 3years & 68 & 55.9 \\
\cline { 2 - 4 } & 4-6 years & 138 & 12.6 \\
\cline { 2 - 4 } & $7-8$ years & 31 & 100.0 \\
\cline { 2 - 4 } & More than 10 & 10 & \\
\cline { 2 - 4 } & Total & 247 & \\
\hline
\end{tabular}

\subsection{Measures of Data Variability and Correlation}

Table 2 presents the study's means, standard deviations, reliability, and correlation results for all variables. Non-Financial Performance has the highest mean of 4.0142 and the lowest standard deviation of .31061, while TMT Shared Responsibility has the lowest mean of 3.9488 and the highest standard deviation of .46605. Furthermore, the scale reliability was within the acceptable range, as the Cronbach' Alpha was greater than.65 for 
all variables, which is acceptable (Nunnally, 1978). Results of correlation indicate that all variables were positively associated with Non-Financial Performance with Innovativeness having the highest relationship with $\mathrm{r}=.682$, $\mathrm{p}$ $<.01$, followed by TMT Shared Responsibility with $\mathrm{r}=.581, \mathrm{p}<.01$ while university reputation has the weakest but positive association with $\mathrm{r}=.199, \mathrm{p}<.01$.

\begin{tabular}{|c|c|c|c|c|c|c|}
\hline Variable $(\mathrm{N}=247)$ & Mean & S.D & Reliability $(\alpha)$ & Correlation & & \\
\hline Non-Financial Performance & 4.0142 & 0.31061 & 0.739 & - & & \\
\hline TMT Shared Responsibility & 3.9488 & 0.46605 & 0.692 & $0.581^{* *}$ & - & \\
\hline Innovativeness & 4.1303 & 0.32414 & 0.656 & $0.682^{* *}$ & $0.511^{* *}$ & - \\
\hline
\end{tabular}

4.3. Factor Analysis

To test for construct validity, the items related to all of the study variables were factor analyzed using principal component analysis with Varimax rotation prior to testing the hypotheses Table 3. Three factors explained 41.95 percent of the variance for the full set of variables, according to the analysis. Non-financial performance was designated as factor one, and it had a five-item loading that explained 16.872 percent of the variance. The second component identified through the research was Innovativeness, which had four items and accounted for 13.71 percent of the variation. TMT Shared Responsibility was the third factor, and it only had three things loaded. This variable accounted for 11.37 percent of the variance.

Table-3. Factor Analysis - KMO and Bartlett's Test

\begin{tabular}{|c|c|}
\hline \multicolumn{2}{|l|}{ Non-Financial Performance } \\
\hline Our hotel continuously aims to maintain or improve its star-rating & Dropped \\
\hline Our customers are likely to return & 0.737 \\
\hline Majority of our employees are full time & 0.617 \\
\hline Customer requirements are met on time & 0.637 \\
\hline corporate sponsorships are offered by our hotel & 0.508 \\
\hline Our hotel guests enjoy relaxation, exercise, and refreshment & dropped \\
\hline We have standard design- facilities, renovations and maintenance systems in place & dropped \\
\hline Customers like the services offered to them by our employees (Removed) & dropped \\
\hline Our hotel is effective in generating high quality solutions (Removed) & dropped \\
\hline We have new customers & 0.643 \\
\hline \multicolumn{2}{|l|}{ TMT Shared Responsibility } \\
\hline As managers we are involved in changing policies that affect a portion of the hotel & dropped \\
\hline We participate in Hiring midlevel management personnel & dropped \\
\hline $\begin{array}{l}\text { Managers are consulted on making capital expenditures greater than } 1 \% \text { of our hotel's } \\
\text { annual budget }\end{array}$ & dropped \\
\hline We participate in making changes in the way hotel firm produces its products/services & 0.697 \\
\hline As managers we discuss expectations of each other & 0.513 \\
\hline $\begin{array}{l}\text { Hotel departments are evaluated on their joint performance instead of separate departmental } \\
\text { performance. }\end{array}$ & 0.54 \\
\hline \multicolumn{2}{|l|}{ Innovativeness } \\
\hline As managers we are effective in making decisions that require high levels of creativity & dropped \\
\hline Our hotel emphasizes pursuing knowledge that fits a changing environment. & 0.566 \\
\hline When drawing up strategies, our hotel easily responds changes in the environment. & 0.755 \\
\hline Our hotel usually makes significant changes in products/services & 0.521 \\
\hline Our employees are rewarded for new ideas & 0.708 \\
\hline Our hotel eliminates products or services in later stages of their life cycle & dropped \\
\hline Our hotel, attaches great importance to research and development activities & dropped \\
\hline In the past one year my department has adopted new services, technologies and processes & dropped \\
\hline Kaiser-Meyer-Olkin Measure of Sampling Adequacy & 0.721 \\
\hline Bartlett's Test of Sphericity Approx. Chi-Square & $1133.174 *$ \\
\hline
\end{tabular}




\subsection{Hypotheses Testing}

To investigate how much variance in non-financial performance of star-rated hotels is accounted for by TMT shared Responsibility in the presence and absence of innovativeness, a four stage hierarchical multiple regression using the enter method was adopted as a suitable method of analysis (Darren \& Paul, 2012). As Table 4 reveals, the control variables of respondents' gender, age, highest level of education and tenure were entered in the first stage (model 1), then the direct effect of TMT Shared Responsibility, was entered in the second stage (model 2), followed by the direct effect plus the moderator (Innovativeness) which were entered at stage three (model 3) and finally at stage four, the moderating effect of Innovativeness on the relationships between the TMT Shared Responsibility and Non-financial performance of star-rated hotels was analyzed (model 4).

In model 1, effect of the control variables (respondents' gender, age, highest level of education and tenure) in this study were examined. Results from Table 4 show the study findings of the control variables' effects on nonfinancial hotel performance. The study shows that gender, significantly predicts non-financial performance of starrated hotels with $\beta=0.251, \mathrm{p}=.005$. Results also show that managers 'age group, significantly predicts nonfinancial performance of star-rated hotels with $\beta=0.251, p=0.034$. In addition, the managers 'education level was not significant with $\beta=-0.061, p=0.349$. Finally, the managers' tenure was significant with $\beta=-0.242, p=0.011$. Further model 1 explains $7.2 \%\left(\mathrm{R}^{2}=0.072\right)$ of the variance in non-financial performance which is statistically significant with $\mathrm{F}(4,242)=10.968, \mathrm{p}=0.000$.

Table-4. Results of hypotheses testing.

\begin{tabular}{|c|c|c|c|c|}
\hline Variables & Model 1 & Model 2 & Model 3 & Model 4 \\
\hline & Beta & Beta & Beta & Beta \\
\hline Gender & $-0.373^{* *}$ & -0.189 & -0.123 & -0.163 \\
\hline Age group & $0.251^{*}$ & 0.191 & $0.175^{*}$ & $0.221^{* *}$ \\
\hline Education Level & -0.061 & -0.035 & 0.020 & -0.032 \\
\hline Tenure & $-0.242^{*}$ & -0.122 & -0.091 & $-0.127^{*}$ \\
\hline TMTSR & & $0.551^{* * * *}$ & $0.298^{* * * *}$ & $2.049 * * *$ \\
\hline Innov. & & & $0.512^{* * *} *$ & $1.686^{* * * *}$ \\
\hline TMT SR*Innov & & & & $-0.996^{* * * *}$ \\
\hline $\mathrm{R}^{2}$ & 0.072 & 0.360 & 0.552 & 0.598 \\
\hline$\Delta \mathrm{R}^{2}$ & 0.072 & 0.289 & 0.192 & 0.046 \\
\hline $\mathrm{F}$ & $4.682 * * *$ & $108.736^{* * * *}$ & $102.799 * * *$ & $27.522^{* * * *}$ \\
\hline
\end{tabular}

In Model 2 of the same Table, results suggested that all control variables were insignificant in this model. In addition, TMT Shared Responsibility was found to have a significant direct effect on non-financial performance with $\beta=0.551, p=0.000$. This model explains $36 \%\left(\mathrm{R}^{2}=0.360\right)$ of the variance in the dependent variable (nonfinancial performance). A change in $\mathrm{R}^{2}\left(\Delta \mathrm{R}^{2}\right)=0.289$ implies that TMT shared responsibility explained $28.9 \%$ of the variance in non-financial performance of star-rated hotels. Findings show that the Model is fit with a statistically significant $\mathrm{F}(1,241)=108.736$ and $p=0.000$. Based on these results, hypothesis $\mathrm{H} 1$ is supported by the study.

In Model 3, the study shows that all control variables except age $(\beta=0.175, p<0.05)$ were found to be insignificant as indicated by $p>$.05. In addition, TMT Shared Responsibility remained significant with $\beta=0.298$, $p$ $=0.000$. Most importantly results showed that Innovativeness had a positive and significant direct effect on perceived non-financial performance with $\beta=0.512, \mathrm{p}=0.000$. This model shows $\mathrm{R}^{2}=0.552, \Delta \mathrm{R}^{2}=0.192$ with a significant $\mathrm{F}(1,240)=102.799, \mathrm{p}=.000$, implying that the model explained $55.2 \%$ of the variance in non-financial performance of star-rated hotels. The change in $\mathrm{R} 2\left(\Delta \mathrm{R}^{2}\right)$ of 0.192 means that while holding constant other factors 
in this model, innovativeness explained $19.2 \%$ of the variance in non-financial performance of star-rated hotels. Based on the above results, hypothesis, $\mathrm{H}_{2}$ is also supported.

Findings in Model 4 reveal that gender and education were insignificant in this model. However, the managers 'age group $(\beta=0.221, \mathrm{p}<.05)$ and the managers' tenure $(\beta=-0.127, \mathrm{p}<.05)$ were significant. Furthermore, TMT Shared Responsibility and Innovativeness remained significant in this model as shown by $\mathrm{p}<.05$. In addition, results showed that Innovativeness has a moderating effect on the relationship between TMT shared responsibility and performance with $\beta=-0.996, p=0.000$. This model shows $\mathrm{R}^{2}=0.598, \Delta \mathrm{R}^{2}=0.046$, a significant $\mathrm{F}=27.522$ and $\mathrm{p}$ $=0.000$. The $\mathrm{R}^{2}=.598$ reveals that all the variables in this model accounts for around $60 \%$ of the variance in nonfinancial performance. On the other hand, a $\Delta \mathrm{R}^{2}=0.046$ indicates that holding constant the control variables, independent variable and the moderator the interaction process explains $4.6 \%$ of the variance in the non-financial performance of star-rated hotels. Based on the above results, hypothesis H3 is also supported by the current study.

These moderation results are further illustrated by Figure 1, which indicates that at low levels of TMT Shared Responsibility, non- financial performance is high with high levels of Innovativeness and vice-versa. This interaction indicates that performance increases with both increase in TMT shared responsibility and innovativeness, the opposite also applies. Hence, Innovativeness acts as a remedy for low TMT Shared Responsibility in enhancing non- financial hotel performance.



\subsection{Discussion, Practical and Theoretical Implications}

This study aimed to establish the interaction effect of innovativeness on TMT Shared Responsibility and NonFinancial hotel performance. Our study results reveal some important theory and practical implications for the hospitality scholars and practitioners. We found that both TMT Shared Responsibility and innovativeness have a significant direct effect on non-financial performance. Further, innovativeness moderates the effect of TMT Shared Responsibility and non-financial performance. The results of our study support and extend previous studies, by García-Granero, Fernández-Mesa, Jansen, and Vega-Jurado (2018); Vij and Bedi (2016) and act as a basis for research and management implications.

Findings revealed that TMT Shared Responsibility has a significant direct effect on non-financial performance. This results is consistent with the findings of García-Granero et al. (2018) who posit that when managers enjoy collective decision-making, they tend to be more productive. It is therefore imperative of for hotel managers to establish mechanisms of departmental coordination, and collective responsibility for the overall hotel performance. 
Besides, our finding lends support to the conclusion that the top team, rather than the top person, has the greatest effects on organizational functioning

We also found that innovativeness is a predictor of non-financial performance which is supported by the notion that innovativeness is not only essential for business survival but also for its higher performance (Wang, Kafouros, Yi, Hong, \& Ganotakis, 2020). Hotel managers should therefore encourage creativity and uniqueness among the employees through rewarding new ideas, products and services to enhance quality of hospitality services (Tajeddini, 2010). Research and development being core to innovativeness, should be prioritised by hotel management to enable hotels meet the ever changing hospitality customer needs.

The study findings in relation to moderation effect of innovativeness was also found it to be significant. We learned that in order for a hotel to enhance its performance, the managers do not have to only have collective idea generation but also aim at idea uniqueness by continuously improving the available resources within the hotel. In this regard, we support the conclusion of Camisón and Monfort-Mir (2012) that; while the service sector is less technologically innovative than the manufacturing sector, innovativeness can be performed on the previous experiences. Besides, Yousaf et al. (2021) support the notion that innovativeness enables firms to easily adapt the necessary changes, which arise due to rapidly changing market trends. Such changes require the combined efforts of hotel human resources but the impact on performance can be greater with ideas that deviate from the normal.

Theoretically, this study contributes to existing literature on the role of TMT Shared Responsibility and innovativeness in influencing performance. It further reveals that innovativeness improves non-financial performance and also acts as a moderator. We also contribute to Resource Based View literature by conceptualizing innovativeness and TMT shared responsibility as intangible resources

\subsection{Limitation and Recommendations for Future Research}

It should be noted however that this study was not without limitations. Data was collected at a point in time which could have caused common method bias. In addition, the study was quantitative in nature basing on primary data obtained using closed ended questionnaires limiting a deeper insight into the respondents' knowledge and practice of the study concepts. Also non-financial performance, innovation and TMT shared Responsibility were measured subjectively. In addition, results of this study focused on only the hotel industry making it difficult to generalize the findings to other sectors.

Future studies should be conducted to include intervening variables that may moderate or even mediate the relationship between the study variables. Also qualitative studies using in-depth interviews should be given consideration to reveal other factors that affect non-financial performance of star-rated hotels other than those considered for the study. Finally, additional research is required to investigate the robustness of our findings and to determine the extent to which our findings can be generalized to other contexts or countries.

\section{CONCLUSION}

This study offers an extensively integrative approach for comprehending TMT Shared Responsibility and Non-Financial Performance of Star-Rated Hotels Moderated by Innovativeness. According to the findings of the study, TMT Shared Responsibility and Innovativeness predict non-financial performance of star-rated hotels. Furthermore, the study confirms that the relationship between TMT Shared Responsibility and Non-financial performance of star-rated hotels is moderated by innovativeness. 
'This implies that the predictive effect of TMT Shared Responsibility increases with increasing innovativeness, implying that the variables used in this research play a significant role in the non-financial performance of starrated hotels, and our research results as well mark some intriguing suggestions for future work.

\section{REFERENCES}

Abernethy, M. A., Bouwens, J., \& Van Lent, L. (2013). The role of performance measures in the intertemporal decisions of business unit managers. Contemporary Accounting Research, 30(3), 925-961. Available at: https://doi.org/10.1111/19113846.12023

Agyapong, A., Essuman, D., \& Afia Kesewa Yeboah, L. (2021). Performance implications of strategic planning and marketing capability in micro and small businesses in an emerging African economy: a contingent resource-based view. Journal of Small Business \& Entrepreneurship, 33(1), 29-48. Available at: https://doi.org/10.1080/08276331.2018.1507415.

Al-Momani, A. M., Mahmoud, M. A., \& Ahmad, M. S. (2018). Factors that influence the acceptance of internet of things services by customers of telecommunication companies in Jordan. Journal of Organizational and End User Computing (JOEUC), 30(4), 51-63. Available at: https://doi.org/10.1080/08276331.2018.1507415.

Anjani, A. M. D. P., \& Yasa, N. N. K. (2019). The role of product innovation in mediating the influence of entrepreneurship orientation on marketing performance (A study on silver craft MSMEs in Celuk, Gianyar). Journal of Business Management and Economic Research, 3(3), 1-18. Available at: https://doi.org/10.29226/tr1001.2019.109.

Asad, M., Sharif, M., \& Hafeez, M. (2016). Moderating effect of network ties on the relationship between entrepreneurial orientation, market orientation, and performance of MSEs. Economics, and Social Sciences, 10(2), 74-81. Available at: https://doi.org/10.24312/paradigms 100207.

Avci, U., Madanoglu, M., \& Okumus, F. (2011). Strategic orientation and performance of tourism firms: Evidence from a developing country. Tourism Management, 32(1), 147-157. Available at: https://doi.org/10.1016/j.tourman.2010.01.017.

Barney, J. (1991). Firm resources and sustained competitive advantage. Journal of Management, 17(1), 99-120.

Camisón, C., \& Monfort-Mir, V. M. (2012). Measuring innovation in tourism from the Schumpeterian and the dynamiccapabilities perspectives. Tourism Management, 33(4), 776-789. Available at: https://doi.org/10.1016/j.tourman.2011.08.012.

Carmona-Márquez, F. J., Leal-Millán, A. G., Vázquez-Sánchez, A. E., Leal-Rodríguez, A. L., \& Eldridge, S. (2016). TQM and business success. International Journal of Quality \& Reliability Management, 33(3), 361-379.

Chen, F.-H., Hsu, T.-S., \& Tzeng, G.-H. (2011). A balanced scorecard approach to establish a performance evaluation and relationship model for hot spring hotels based on a hybrid MCDM model combining DEMATEL and ANP. International Journal of Hospitality Management, $30(4), \quad 908-932 . \quad$ Available at: https://doi.org/10.1016/j.ijhm.2011.02.001.

Covin, J. G., \& Miller, D. (2014). International entrepreneurial orientation: Conceptual considerations, research themes, measurement issues, and future research directions. Entrepreneurship Theory and Practice, 38(1), 11-44. Available at: https://doi.org/10.1111/etap.12027.

Darren, G., \& Paul, M. (2012). IBM SPSS statistics 19 step by step. A simple guide and reference (12th ed.): Pearson.

Dawa, S., Namatovu, R., Mulira, F., Kyejjusa, S., Arinaitwe, M., \& Arinaitwe, A. (2021). Entrepreneurial competences and growth of female-owned enterprises: thTe mediation role of absorptive capacity. International Journal of Gender and Entrepreneurship, 13(1), 30-49. 
Errays, N. A., \& Hattabou, A. (2015). L'effet modérateur de la confiance et de l'engagement sur la relation entre l'orientation entrepreneuriale et la performance. La Revue Gestion et Organisation, 7(1), 57-68. Available at: https://doi.org/10.1016/j.rgo.2015.01.001.

García-Granero, A., Fernández-Mesa, A., Jansen, J. J., \& Vega-Jurado, J. (2018). Top management team diversity and ambidexterity: The contingent role of shared responsibility and CEO cognitive trust. Long Range Planning, 51(6), 881893. Available at: https://doi.org/10.1016/j.lrp.2017.11.001.

Glynn, M. S., \& Chen, S. (2009). Consumer-factors moderating private label brand success: Further empirical results. International Journal of Retail $\&$ Distribution Management, 37(11), 896-914. Available at: https://doi.org/10.1108/09590550910999343.

Gomezelj, O. D., \& Smolčić, J. D. (2016). The influence of intellectual capital on innovativeness and growth in tourism SMEs: Empirical evidence from Slovenia and Croatia. Economic Research, 29(1), 1075-1090. Available at: https://doi.org/10.1080/1331677x.2016.1211946.

Grissemann, U., Plank, A., \& Brunner-Sperdin, A. (2013). Enhancing business performance of hotels: The role of innovation and customer orientation. International Journal of Hospitality Management, 33, 347-356. Available at: https://doi.org/10.1016/j.ijhm.2012.10.005.

Hatak, I., Kautonen, T., Fink, M., \& Kansikas, J. (2016). Innovativeness and family-firm performance: The moderating effect of family commitment. Technological Forecasting and Social Change, 102, 120-131. Available at: https://doi.org/10.1016/j.techfore.2015.02.020.

Hernández-Perlines, F., Ibarra Cisneros, M. A., Ribeiro-Soriano, D., \& Mogorrón-Guerrero, H. (2020). Innovativeness as a determinant of entrepreneurial orientation: Analysis of the hotel sector. Economic Research, 33(1), 2305-2321. Available at: https://doi.org/10.1080/1331677x.2019.1696696.

Hollingshead, A. B., Brandon, D. P., Yoon, K., \& Gupta, N. (2011). Communication and knowledge-sharing errors in groups: A transactive memory perspective. In H. E. Canary \& R. D. McPhee (Eds.), Communication and organizational knowledge: Contemporary issues for theory and practice (pp. 133-150): Routledge/Taylor \& Francis Group.

Hsieh, L.-F., \& Lin, L.-H. (2010). A performance evaluation model for international tourist hotels in Taiwan-An application of the relational network DEA. International Journal of Hospitality Management, 29(1), 14-24. Available at: https://doi.org/10.1016/j.ijhm.2009.04.004.

Kantur, D. (2016). Strategic entrepreneurship: Mediating the entrepreneurial orientation-performance link. Management Decision, 54(1), 24-43. Available at: https://doi.org/10.1108/md-1 1-2014-0660.

Kusumasari, L. (2018). Functions, age, education, tenure of CEO, and employee commitment toward firm performance. KnE Social Sciences, 3(1), 64-73.

Li, M., Liu, H., \& Zhou, J. (2018). G-SECI model-based knowledge creation for CoPS innovation: The role of grey knowledge. Journal of Knowledge Management, 22(4), 887-911. Available at: https://doi.org/10.1 108/JKM-10-2016-0458.

Ling, Y., Simsek, Z., Lubatkin, M., \& Veiga, J. (2008). The impact of transformational CEOs on the performance of small- to medium-sized firms: Does organizational context matter? The Journal of Applied Psychology, 93, 923-934. Available at: https://doi.org/10.1037/002 1-9010.93.4.923.

Martin, J. A. (2011). Dynamic managerial capabilities and the multibusiness team: The role of episodic teams in executive leadership groups. Organization Science, 22(1), 118-140.

Mihalache, O. R., Jansen, J. J., Van den Bosch, F. A., \& Volberda, H. W. (2014). Top management team shared leadership and organizational ambidexterity: A moderated mediation framework. Strategic Entrepreneurship Journal, 8(2), 128-148. Available at: https://doi.org/10.1002/sej.1168. 
Mitchelmore, S., \& Rowley, J. (2013). Entrepreneurial competencies of women entrepreneurs pursuing business growth. Journal of Small Business and Enterprise Development, 20(1), 125-142. Available at: https://doi.org/10.1108/14626001311298448.

Nath, P., Nachiappan, S., \& Ramanathan, R. (2010). The impact of marketing capability, operations capability and diversification strategy on performance: A resource-based view. Industrial Marketing Management, 39(2), 317-329. Available at: https://doi.org/10.1016/j.indmarman.2008.09.001.

Nunnally, J. C. (1978). Psychometric theory (2nd ed.). New York: McGraw-Hill.

O'Reilly, C. A., Caldwell, D. F., Chatman, J. A., Lapiz, M., \& Self, W. (2010). How leadership matters: The effects of leaders' alignment on strategy implementation. The Leadership Quarterly, 21(1), 104-113. Available at: https://doi.org/10.1016/j.leaqua.2009.10.008.

Omagon, J. (2019). Analysis of the Impact of Working capital management practices on financial performance: A study of hotels in Kampala under UHOA. Doctoral Dissertation, Makerere University.

Omerzel, D. G., \& Antoncic, B. (2008). Critical entrepreneur knowledge dimensions for the SME performance. Industrial Management \& Data Systems, 108(9), 1182-1199.

Ongori, J. K., Iravo, M., \& Munene, C. E. (2013). Factors affecting performance of hotels and restaurants in Kenya: A case of Kisii County. Interdisciplinary Journal of Contemporary Research in Business, 12(4), 897 - 928.

Prifti, R., \& Alimehmeti, G. (2017). Market orientation, innovation, and firm performance—an analysis of Albanian firms. Journal of Innovation and Entrepreneurship, 6(1), 1-19. Available at: https://doi.org/10.1186/s13731-017-0069-9.

Sainaghi, R. (2011). RevPAR determinants of individual hotels. International Journal of Contemporary Hospitality Management, 23(3), 297-311.

Sainaghi, R., Phillips, P., \& Zavarrone, E. (2017). Performance measurement in tourism firms: A content analytical metaapproach. Tourism Management, 59, 36-56. Available at: https://doi.org/10.1016/j.tourman.2016.07.002.

Sarmah, B., Kamboj, S., \& Rahman, Z. (2017). Co-creation in hotel service innovation using smart phone apps: an empirical study Bijoylaxmi Sarmah, Shampy Kamboj, Zillur Rahman. Management, 29(10), 2647-2667. Available at: https://doi.org/10.1108/ijchm-12-2015-0681.

Shrestha, M. (2019). Influence of age group on job satisfaction in Academia. SEISENSE Journal of Management, 2(3), 30-41. Available at: https://doi.org/10.33215/sjom.v2i3.141.

Sofronov, B. (2018). The development of the travel and tourism industry in the world. Annals of Spiru Haret University. Economic Series, 18(4), 123-137.

Statistics, U. B. O. (2017). Uganda demographic and health survey 2016: Key indicators report: UBOS, and Rockville Maryland.

Tajeddini, K. (2010). Effect of customer orientation and entrepreneurial orientation on innovativeness: Evidence from the hotel industry in Switzerland. Tourism Management, 31(2), 221-231. Available at: https://doi.org/10.1016/j.tourman.2009.02.013.

Teixeira, S. J., \& Ferreira, J. J. (2019). Entrepreneurial artisan products as regional tourism competitiveness. International Journal of Entrepreneurial Behaviour and Research, 25(4), 652-673. Available at: https://doi.org/10.1 108/ijebr-01-2018-0023.

Vij, S., \& Bedi, H. S. (2016). Effect of organisational and environmental factors on innovativeness and business performance relationship. International Journal of Innovation Management, $20(03), 1650037$.

Wadongo, B., Odhuno, E., Kambona, O., \& Othuon, L. (2010). Key performance indicators in the Kenyan hospitality industry: A managerial perspective. Benchmarking, 17(6), 858-875. Available at: https://doi.org/10.1108/14635771011089764.

Wang, X., \& Dass, M. (2017). Building innovation capability: The role of top management innovativeness and relativeexploration orientation. Journal of Business Research, 76, 127-135. Available at: https://doi.org/10.1016/j.jbusres.2017.03.019. 
Wang, C., Kafouros, M., Yi, J., Hong, J., \& Ganotakis, P. (2020). The role of government affiliation in explaining firm innovativeness and profitability in emerging countries: Evidence from China. Journal of World Business, 55(3), 101047. Available at: https://doi.org/10.1016/j.jwb.2019.101047.

West, G. P., \& Noel, T. W. (2009). The impact of knowledge resources on new venture performance. Journal of Small Business Management, 47(1), 1-22. Available at: https://doi.org/10.1111/j.1540-627x.2008.00259.x.

Yousaf, S., Anser, M. K., Tariq, M., Sahibzada Jawad, S. U. R., Naushad, S., \& Yousaf, Z. (2021). Does technology orientation predict firm performance through firm innovativeness? World Journal of Entrepreneurship, Management and Sustainable Development, 17(1), 140-151. Available at: https://doi.org/10.1108/wjemsd-11-2019-0091.

Online Science Publishing is not responsible or answerable for any loss, damage or liability, etc. caused in relation to/arising out of the use of the content. Any queries should be directed to the corresponding author of the article. 